\title{
The Relationship between Consumption of Fast Food with Level of Serum Folat among Nursing Students of Islamic Azad University, Tehran Medical Sciences Branch in 2016
}

\author{
Naghibeiranvand Mehran*, Moshtagheshgh Zahra \\ Islamic Azad University Tehran Medical Sciences Branch, Tehran, Iran \\ Email: *mehranbeiranvandmsc@gmail.com
}

How to cite this paper: Mehran, N. and Zahra, M. (2017) The Relationship between Consumption off Fast Food with Level of Serum Folate among Nursing Students of Islamic Azad University, Tehran Medical Sciences Branch in 2016. International Journal of Clinical Medicine, 8, 338-343. https://doi.org/10.4236/ijcm.2017.85031

Received: January 19, 2017

Accepted: May 28, 2017

Published: May 31, 2017

Copyright (c) 2017 by authors and Scientific Research Publishing Inc. This work is licensed under the Creative Commons Attribution International License (CC BY 4.0).

http://creativecommons.org/licenses/by/4.0/

\begin{abstract}
In recent decades, substantial increase in average weight of individuals has been seen in rich countries. Such changes are the result of significant changes in pattern of people's lives. One of these issues is increasing levels in consumption of fast foods or processed foods. According to experts, the consumption of processed foods, because of having high-calories and trans-fatty acids, is fattening and harmful. In this study, the researchers after obtaining permission from the ethics committee and head of the School of Nursing, introduced themselves to nursing students then, samples were randomly selected among those who are eligible for the study. Before performing to complete the questionnaire and relevant experiments, testimonial were asked from the subjects. At the end of the study, results were suggested that, levels of Serum folate between males and females and also among married and single people were equivalent. Level of Serum folate among those students who usually have anemia in their families is significantly lower than those ones who have not anemia in their families $(P=0.003)$. There was a significant relationship between age and semester with levels of folate $(P<0.05)$; i.e. by increasing age and educational terms, levels of serum folate would be reduced. The level of serum folate among students who smoke is lesser than those do $\operatorname{not}(P=0.001)$.
\end{abstract}

\section{Keywords}

Fast Food, Serum Folate, Nursing Students

\section{Introduction}

Anemia is one of the most common health problems which according to the 
World Health Organization, is more common in South Asia and Africa compared to the rest of the world [1]. Nutritional anemia is a major problem around the world especially in developing countries. Although iron-deficiency anemia is the most common cause of anemia; however, lack of vitamins such as B6, B12 and folic acid is also causing anemia. These micronutrients are affected directly by the increasing hemoglobin synthesis or indirectly by rising absorption of iron [2]. Studies show, increasing consumption of fast foods is related with getting more energy and obesity and also with less consumption of fruits, vegetables and healthy foods among children, adolescents and adults. Increasing the proportion of high-fat diets and high amount of energy such as fast foods along with reducing physical activities and doing works in sitting status and also lack of movement is some of important factors for gaining weight. Most of people in order to overcome emotion, stress and anxiety problems are overeating. Meantime, students, because of special circumstances, are capable of facing with stress, anxiety and poor dietary patterns (processed foods). Each of these factors can cause changes in their healthy lives [3]. By increasing rate of anemia caused by iron and folic acid deficiency and also financial crisis, the role of lifestyle modification including nutrition is more considerable than before [4].

\section{Methodology}

This research was descriptive-correlational that shows the relationship between fast food consumption with levels of serum folate. Descriptive-correlational is a study that the researchers clearly define the variables without any interference or manipulation of them. In other words, it is a study in which the researchers try to discover and define the relationship among variables [5]. In this study, the researchers selected randomly their samples among nursing students of Islamic Azad University of Tehran Medical Sciences branch who had eligible criteria for the study of October 2015 until December 2016, testimonial were asked from the subjects, then at the presence of the researcher questionnaires were completed. Questionnaire was inclusive three branch principal: Introduce characteristic, present illness history, nutrition and meat habits. In cases where students were academically busy, researcher went to School of Nursing or subordinate hospital of Islamic Azad University of Tehran Medical Sciences branch in other times in order to collect the questionnaires. After completing the questionnaires, blood samples were taken for testing folate among those students, who met the criteria for the study, then, the samples were sent to Bu-Ali Hospital laboratory (subordinate to Islamic Azad University of Tehran Medical Sciences branch)and level of folate serum were tested. The time of testing was at a particular time and day and also at the presence of the researchers. After collecting the questionnaires and getting the answer of tests, they were analyzed at the next step. Data analysis was done by SPSS v. 20. Descriptive statistic (frequency, mean, standard deviation) and inferential tests (independent T, Pearson correlation coefficient, ANOVA and Scheffe post hoc test) methods were used. 


\section{Findings}

In this chapter, collected data were analyzed. In order to describe data, statistical indicators such number, percent, minimum, maximum, mean and standard deviation are used; and for data analysis t-test, Pearson correlation coefficient, ANOVA and Schiff post hoc test were applied. Relationships between consumption of processed foods with levels of folate serum have been studied among nursing students of Islamic Azad University. The population sample was about 100 students ( 34 males and 66 females) that are randomly selected among students of mentioned School on academic year of 2016. Table 1 shows the demographic information results. Table 2 shows the Correlation of folate serum level with monthly consumption of fast food and Table 3 shows Mean and SD of folate serum levels among nursing students also Table 4 shows Correlation between levels of folate serum with age, academic semester, height, weight and BMI.

Table 1. Absolute and relative frequency distribution among nursing students of Islamic Azad University, Tehran Medical Sciences branch in year of 2016.

\begin{tabular}{|c|c|c|}
\hline Variable & & $\mathrm{N}(\%)$ \\
\hline \multirow{2}{*}{ Gender } & Male & $34(34)$ \\
\hline & Female & $66(66)$ \\
\hline \multirow{2}{*}{ Marital Status } & Single & $30(30)$ \\
\hline & Married & $70(70)$ \\
\hline \multirow{6}{*}{ Semester } & Three & $10(10)$ \\
\hline & Four & $18(18)$ \\
\hline & Five & $9(9)$ \\
\hline & Six & $27(27)$ \\
\hline & Seven & $29(29)$ \\
\hline & Eight & $9(9)$ \\
\hline \multirow{4}{*}{$\begin{array}{l}\text { Employment } \\
\text { Condition }\end{array}$} & No-Job & $57(57)$ \\
\hline & Labor & $15(15)$ \\
\hline & Employee & $16(16)$ \\
\hline & Self-Employed & $12(12)$ \\
\hline \multirow{2}{*}{ Residency Status } & With Family & $58(58)$ \\
\hline & Dorm & $24(24)$ \\
\hline \multirow{2}{*}{ Smoking } & No & $10(10)$ \\
\hline & Yes & $90(90)$ \\
\hline \multirow{2}{*}{ Alcohol Drinking } & No & $14(14)$ \\
\hline & Yes & $86(86)$ \\
\hline \multirow{2}{*}{ Having Specific Disease } & No & $7(7)$ \\
\hline & Yes & $93(93)$ \\
\hline \multirow{2}{*}{ Records of Anemia } & No & $14(14)$ \\
\hline & Yes & $86(86)$ \\
\hline
\end{tabular}


Table 2. Correlation of folate serum level with monthly consumption of fast food among students of Islamic Azad University, Tehran Medical Sciences branch in year of 2016.

\begin{tabular}{cccc}
\hline Variable & Mess Code & Correlation Coefficient & $p$-value \\
\hline Hamburgers & 100 & -0.257 & 0.01 \\
Sausage, Salami and Ham & 100 & -0.368 & 0.0001 \\
Chicken Nuggets & 100 & -0.12 & 0.235 \\
Fish and Fried Shrimp & 100 & -0.186 & 0.064 \\
Chips, Fries & 100 & -0.384 & 0.0001 \\
Pizza & 100 & -0.401 & 0.0001 \\
Spaghetti and Pasta & 100 & -0.207 & 0.039 \\
Sweets & 100 & -0.342 & 0.0001 \\
Mayonnaise Souse & 100 & -0.205 & 0.041 \\
\hline
\end{tabular}

Table 3. Mean and SD of folate serum levels among nursing students of Islamic Azad University, Tehran Medical Sciences branch in year of 2016.

\begin{tabular}{|c|c|c|c|c|c|c|}
\hline Variable & Gender & Mess Code & $\mathbf{M}$ & $\mathrm{SE}$ & $\mathrm{T}$ & $p$-value \\
\hline \multirow[b]{2}{*}{ Folate Serum } & Male & 34 & 5.89 & 5.81 & \multirow[b]{2}{*}{0.07} & \multirow[b]{2}{*}{0.944} \\
\hline & Female & 66 & 5.97 & 5.39 & & \\
\hline \multirow{2}{*}{ Folate } & Single & 70 & 5.91 & 5.4 & \multirow{2}{*}{0.103} & \multirow{2}{*}{0.918} \\
\hline & Married & 30 & 6.03 & 5.85 & & \\
\hline \multirow[b]{2}{*}{ Folate } & With Family & 58 & 5.38 & 5.57 & \multirow[b]{2}{*}{1.23} & \multirow[b]{2}{*}{0.932} \\
\hline & Dorm & 42 & 6.72 & 5.39 & & \\
\hline \multicolumn{7}{|c|}{ Smoking } \\
\hline \multirow{2}{*}{ Folate } & Yes & 10 & 1.89 & 2.92 & \multirow{2}{*}{4.1} & \multirow{2}{*}{0.001} \\
\hline & No & 90 & 6.35 & 5.55 & & \\
\hline \multicolumn{7}{|c|}{ Alcohol Drinking } \\
\hline \multirow{2}{*}{ Folate } & Yes & 14 & 6.2 & 5.52 & \multirow{2}{*}{0.185} & \multirow{2}{*}{0.854} \\
\hline & No & 86 & 5.9 & 5.54 & & \\
\hline \multicolumn{7}{|c|}{ Records of Other Disease } \\
\hline \multirow[b]{2}{*}{ Folate } & Yes & 7 & 6.01 & 6.47 & \multirow[b]{2}{*}{0.034} & \multirow[b]{2}{*}{0.973} \\
\hline & No & 93 & 5.94 & 5.47 & & \\
\hline \multirow[b]{3}{*}{ Folate Serum } & \multicolumn{4}{|c|}{ Records of Anemia in Family } & \multirow{4}{*}{3.35} & \multirow[b]{3}{*}{0.003} \\
\hline & Yes & 14 & 2.52 & 3.82 & & \\
\hline & No & 86 & 6.5 & 5.55 & & \\
\hline \multicolumn{6}{|c|}{ Job Condition } & \\
\hline \multirow{4}{*}{ Folate } & Student & 57 & 6.28 & 0.69 & \multirow{4}{*}{0.454} & \multirow{4}{*}{0.653} \\
\hline & LABOR & 15 & 6.64 & 5.8 & & \\
\hline & Employee & 16 & 5.26 & 4.95 & & \\
\hline & Self Employed & 12 & 4.39 & 5.25 & & \\
\hline
\end{tabular}


Table 4. Correlation between levels of folate serum with age, academic semester, height, weight and BMI (body mass index) among nursing students of Islamic Azad University, Tehran Medical Sciences branch in year of 2016.

\begin{tabular}{cccc}
\hline Variable & Mess Code & Correlation Coefficient & $p$ value \\
\hline Age & 100 & -0.227 & 0.023 \\
Academic Semester & 100 & -0.23 & 0.021 \\
Height & 100 & 0.075 & 0.458 \\
Weight & 100 & 0.141 & 0.16 \\
BMI & 100 & 0.125 & 0.216 \\
\hline
\end{tabular}

Ahmadi Khatir (2015) investigated the relationship between consumption of fast food with anemia in patients. The study was done over 100 patients who came to subordinated hospitals of Mazandaran University of Medical Sciences. The average age on that study was about 29 years-old while on the present is 22 years-old. According to Table 4, 70\% of the subjects in our study were single, while this amount was about 33 percent in Ahmadi Khatir study. In our study the average body mass was about 22.55; however, this amount was about 24 in Ahmadi Khatir study; i.e. the average body for majority of the participants in both studies were within the normal range of 25 to 18.5. In Ahmadi Khatir study, 86 percent of subjects were lived in the city and 14 percent were in rural areas; however, in our study, all subjects, i.e. 100 percent of them were lived in the cities.

Farzaneh et al. [6] have done a study to examine the consumption of fast food among students of Khalkhalcity, EA, Iran. The numbers of participants were 150 people, of which $28 \%$ were male and 72 percent were female; while, of 100 subjects in the present study $66 \%$ were female and $34 \%$ were male.

The findings of Shojaeian et al. [7] in their study "comparison of folate serum among pregnant women with and without preeclampsia" showed that there is a meaningful differences in folate serum $(P=0.001)$. The average amount of folate serum in patients without preeclampsia were about $1.42 \mathrm{ng}$ per liter and in the group with preeclampsia were $0.87 \mathrm{ng}$ per litre, but the mean for folate serum was about 5.94 in present study. Masoud et al. [8] have done a research to evaluate levels of folic acid serum in patients with/without ischemic stroke. This study has been done over 40 patients with cerebral stroke and 40 healthy persons. The average level of folic acid serum in patients with cerebral stroke was about 8.40 and for healthy group was 10.87; which this average was higher than of ours study. In a study conducted by Saboktakin et al. [9] on 70 patients with depression Folate deficiency was observed in 51.4 percent of subjects. But in the present study, folate deficiency was observed in 53 percent of subjects. This study was conducted over 100 nursing students.

\section{Conclusion}

Levels of folate serum are equal in males and females and also in married and single people. Levels of folate serum in students that in their families anemia ex- 
ist, are significantly lesser than those who do not have anemia in their families $(P$ $=0.003)$. No statistically significant relationships between age and academic semesters with levels of folate have been observed $(P<0.05)$; by aging and passing educational semesters, levels of folate serum are reduced. Also, levels of folate serum in students who smoke were lesser than those do not smoke $(P=$ $0.001)$.

\section{Suggestions for Further Studies}

1) Examining factors such as vitamins in B group in a similar study;

2) The relationship between consumption of processed food with levels of folate serum among non-healthy (patients) group;

3) The knowledge and attitude of students towards fast food;

4) The effect of fast foods and reduction of folic acid on mental health;

5) The relationship between consumption of fast foods and gaining weight;

6) Evaluation of folate serum amount among individuals.

\section{References}

[1] AhmadiKhatir, S.H. (2015) The Relationship between Consumption of Fast Foods with Patients Who Have Anemia Came to Subordinated Hospitals of Mazandaran University of Medical Sciences.

[2] Lindström, E., Hossain, M.B., Lönnerdal, B., Raqib, R., El Arifeen, S. and Ekström, E.C. (2011) Prevalence of Anemia and Micronutrient Deficiencies in Early Pregnancy in Rural Bangladesh, the MINIMat Trail. Acta Obstetricia et Gynecologica Scandinavica, 90, 47-56. https://doi.org/10.1111/j.1600-0412.2010.01014.x

[3] Nishitani, N., Sakakibara, H. and Akiyama, I. (2009) Eating Behavior Related to Obesity and Job Stress in Male Japanese Workers. Nutrition, 25, 45-50. https://doi.org/10.1016/j.nut.2008.07.008

[4] Butterworth, S.W. (2010) Influencing Patient Adherence to Treatment Guidelines. Journal of Managed Care Pharmacy, 14, 21-24. https://doi.org/10.18553/jmcp.2008.14.S6-B.21

[5] Hojjati, H. and Sharifnia, S.H. (2015) Methods and Statistics in Nursing Research. JameheNegar, Tehran.

[6] Farzaneh, E., Mohamadjani, B., Mohammadi, F., Matlabi, F. and Mehraban, Z. (2015) Study of Fast Foods Consumption in Students of Khalkhal City, Ardabil, University of medical sciences.

[7] Shojaeian, Z., Dalir, Z. and Mahdavian, M. (2014) Comparison of Folate Serum Levels in Pregnant Women with/without Preeclampsia. Iranian Journal of Obstetrics, Gynecology and Infertility, 16, 16-21.

[8] Masood, A., Kucheki, E. and Mousavi, G.A. (2010) Levels of Homocysteine Serum, Folic Acid and Vitamin B12 in Patients with Ischemic Cerebral Stroke. ScientificResearch Journal of Military Medical University of the Islamic Republic of Iran Army, No. 3, 173-169.

[9] Saboktakin, M., Pour GhasemGorgi, B., Mahbub, S. and Pour Afkari, N. (2008) Assessing the Status of Folic Acid and Vitamin B12 in Patients with Depression. $U r$ mia Medical Journal, No. 2, 19-112. 
Submit or recommend next manuscript to SCIRP and we will provide best service for you:

Accepting pre-submission inquiries through Email, Facebook, LinkedIn, Twitter, etc. A wide selection of journals (inclusive of 9 subjects, more than 200 journals)

Providing 24-hour high-quality service

User-friendly online submission system

Fair and swift peer-review system

Efficient typesetting and proofreading procedure

Display of the result of downloads and visits, as well as the number of cited articles Maximum dissemination of your research work

Submit your manuscript at: http://papersubmission.scirp.org/

Or contact ijcm@scirp.org 